\title{
DISTANCE EDUCATION IN UNIVERSITIES OF MODERN RUSSIA
}

\author{
Tatyana Zhdanova ${ }^{1}$, Anna Makarova ${ }^{2}$, Marina Denisova ${ }^{3}$, Galina Romanova ${ }^{4}$ \\ ${ }^{1}$ Candidate of Philology, Voronezh State Technical University, 20 years of October Street, 84, \\ Voronezh, Russia, E-mail: zhdanovsilver@mail.ru \\ ${ }^{2}$ Candidate of Philology, Associate Professor, Voronezh State Technical University, 20 years of \\ October Street, 84, Voronezh, Russia, E-mail: Annasaborowskaja2017@yandex.ru \\ ${ }^{3}$ Candidate of Philology, Associate Professor, Voronezh State Technical University, 20 years of \\ October Street, 84, Voronezh, Russia, E-mail: deni-mar@list.ru \\ ${ }^{4}$ Candidate of Philology, Associate Professor, Voronezh State Technical University, 20 years of \\ October Street, 84, Voronezh, Russia, E-mail: rg.victory@yandex.ru
}

\begin{abstract}
The article shows that most Russian universities are only at the initial stage of introducing modern distance learning technologies in the educational process, and the main barriers to the development of distance learning technologies in higher education are: the high cost of developing, introducing e-learning, the lack of necessary technical support, a small number of qualified teachers for the introduction of distance learning, the lack of an exact number of universities for e-learning courses.

At the same time, an analysis of the foreign experience in the application of these technologies testifies to their demand at universities in the developed countries of the world, which is determined by the comparable quality of foreign distance learning and traditional full-time education.
\end{abstract}

Keywords: education, university, society, state, student.

\section{INTRODUCTION}

The Russian system of higher education has a fundamental scientific base, which makes it possible to prepare a comprehensively developed graduate, but the new era of information and globalization in education require its modernization and the application of new approaches to the organizational activities of higher education. Classical teaching methods (training using paper textbooks, traditional lectures, seminars, etc.) do not fully utilize the full potential of information technology in education, available to teachers and students today. Often, when using traditional teaching methods, students receive outdated information that does not correspond to modern realities, which cannot become the basis for future professional activity. The importance of resolving the problem of the correspondence of the level of higher education to the trends of the time is determined by the powerful influence of this institution on the formation of personality, social groups, spiritual, moral, economic potential of society, on the success of human adaptation in the modern globalizing world. 
This necessitates the modernization of higher education, the development of innovative areas of study, combining flexibility, scalability, ease of obtaining knowledge, accessibility for students, based on modern information technologies, able to meet the needs of students in obtaining relevant information for professional and personal growth, which, in ultimately, it is an objectively necessary condition for Russian higher education to enter the world educational space.

\section{METHODOLOGY}

The information base for the study was legal documents on higher education in the Russian Federation, official statistics, research results of domestic and foreign sociologists in the field of distance higher education, Russian and international resources of the global Internet.

In the process of writing the article, general scientific methods were used, such as analogy, analysis, synthesis. The data were interpreted by methods of grouping, ranking and classification, also used methods of logical, systematic analysis of information and traditional methods of sociological research: document analysis, statistical review, generalization of modern literature, periodicals.

\section{DISCUSSION}

The main directions of modernization of Russian higher education have become the subject of research by researchers S. L. Katanandova, V. Yu. Pashkus N.F. Naumova, in which they argue the need to modernize the system of Russian education, critically analyze its current state, as well as the consequences of previous reforms, come to the conclusion about the catch-up nature of modernization processes in Russian education. Scientific works B.A. Sazonova devoted to the study of the main problems and ways of modernizing domestic education, as well as the principles of the formation of innovative mechanisms for the development of education and the management of these processes.

The consideration of education as a social institution that forms the basic values and guidelines of the person, which are in demand in fulfilling social roles in society, was described in the classical works of $\mathrm{E}$. Durkheim, M. Weber, and N. Smelser. The study of the influence of the institute of education on the social transformations of public life was carried out by A. Bodalev Osipov, Berdyaev, B. Berger, R. Collins, G. Tarde, V.V. Gavrilyuk. Their work is dedicated to identifying the role of education in society and determining measures of its influence on social and managerial systems.

\section{RESULTS}

The theoretical model of the organization of distance learning for students is a unity of interconnected and interdependent components: conceptually targeted, activity-methodical, and logical-substantive. The conceptual-target component of the theoretical model of the organization is built on the basis of personalprofessional centering of the designed model; a system-competency-based approach to the design of content, forms, methods and means of distance learning; a synergistic approach to determining the conditions of self-organization in a simulated pedagogical system; personal-activity approach in a subjectoriented management of distance learning. The activity-methodological component provides for a flexible combination of independent educational and educational research activities of students with various sources of information, operational systematic interaction (full-time and distance) with the leading teacher of the course, tutors and consultants, and group work of students. The logical-substantive component establishes the conformity of the content of specific stages of vocational education, in particular adaptation, initial vocational training, orientation in the profession, professional self-realization, postgraduate) and the stages of pre-graduation (presentation of the specialty - tyotorial - control and certification test work - practice - final state certification - graduate employment - postgraduate monitoring).

The effectiveness of the implementation of the distance learning model of students is due to the presence of the following pedagogical conditions in the educational institution: methodological (scientific and theoretical justification of the model of organization), regulatory and organizational (package of local regulatory acts), organizational and procedural (rational distribution of content, forms and methods of distance learning), didactic (design and use of educational complexes), personnel (psychological, pedagogical and scientificmethodical kai training implementing distance learning).

To assess the effectiveness of the model for organizing distance learning of students at a university, the categories of quality assessment of higher professional education should be used - a set of basic criteria characterizing the professional competence of graduates (the formation of key, general professional and special competencies; professional self-determination; professional self-realization). 


\section{CONCLUSION}

In general, the results of the experimental work confirm the assumption that a scientifically based model for organizing distance learning for students allows the university to effectively solve the problems of professional training of top managers and ensure professional self-realization of persons studying remotely.

Teachers and organizers prepare textbooks to ensure the full preparation of a competitive graduate of distance education in a higher educational institution.

However, the results of the study do not claim to be an exhaustive consideration of the problem. The prospects for this area of work are the implementation of the proposed recommendations, as well as the study of the following aspects of the problem: scientific and methodological substantiation of the content and methods of various types of educational activities of distance learning students; development of teaching aids, software, didactic materials for independent work of students.

\section{REFERENCE LIST}

Baranov A. P. Ivanova N. G. (2003) Influence of social differentiation on educational orientations of citizens. Sociological research. №. 6. Pp. 72-78. (in Russ).

Bykovitskaya N. D. (2000) Development of information technologies in education. Distance and virtual learning. № 9. Pp. 11-13. (in Russ).

Devyatko I. F. (2002) Methods of sociological research. Moscow: University. 296 p. (in Russ).

Durgeim E. (1996) Sociology of education. M.: intor. 80 p. (in Russ).

Ershov B.A. (2010) The Russian Orthodox Church and secular power in the Voronezh province in the XIX early XX centuries. GOU VPO "Voronezh State Technical University". Voronezh. 167 p. (in Russ).

Ershov B.A. (2010) The system of spiritual education in Voronezh province in the 19th century. Education and Society. №. 5 (64). Pp. 105-108. (in Russ).

Ershov B.A., Fursov V.N. (2018) The Russian Church in the State Mechanism of Russia. Bulletin SocialEconomic and Humanitarian Research. № 1. Pp. 32-37.(in Engl).

Ershov B.A., Perevozchikova L.S., Romanova E.V. (2019) Globalization and Intensification of Spiritual Values in Russia in the Philosophical Aspect. 6th International Conference on Education and Social Sciences Abstracts \& Proceedings. Pp. 208-212. (in Engl).

Ershov B.A., Perevozchikova L.S., Romanova E.V., Ashmarov I.A. (2019) The Concept of Spirituality in Social Philosophy. Smart Innovation, Systems and Technologies. T. 139. Pp. 688-694. (in Engl).

Gershunsky B. S. (1987) Computerization in the field of education: problems and prospects. 264 p. (in Russ).

Isaev E. (2012) Introduction to the anthropology of education. monograph. Birobidzhan: publishing house of Sholom Aleichem vocational school. 215 p. (in Russ).

Kolganov E. A. (2008) Distance educational services: needs of the population. Ural sociologists in the allRussian space. Yekaterinburg. Pp. 87-88. (in Russ).

Nazarova T. S. (1998) Means of training. Technology of creation and use. Moscow. 203 p. (in Russ).

Perevozchikova L.S., Ershov B.A., Ashmarov I.A., Volkova E.A. (2017) Role of Russian Orthodox Church in life of peasants in Russia in XIX - the beginning of the XX-th centuries Bylye Gody. Russian historical journal. №. 43 (1). Pp. 121-128. (in Engl).

Radaev V. V. (2008) Strategies for the development of Russian universities: answers to new challenges. Moscow: Max Press. 112 p. (in Russ).

Romanova E.V., Perevozchikova L.S., Ershov B.A. (2017) The Lifestyle of the Human Being in the Information Society. 3rd International Conference on Advances in Education and Social Sciences Proceedings of ADVED Pp. 950-954. (in Engl). 
Sorokina N. D. (2009) Introduction of distance education in higher education. Sociology of education, Moscow: SSU Publishing house, №. 5. Pp. 51-60. (in Russ).

Syulkova N. V. (2005) Distance learning-form or technology? Distance and virtual learning. №. 8. Pp. 52-55.

Volkova E.A., Frolova E.V., Ashmarov I.A. (2015) To the question of the formation of trends in the higher education system in the framework of modern globalization processes. Modern problems of science and education. №. 1-1. P. 975. (in Russ).

Zakharchenko M. V. (2002) Tradition in history: experience of typological interpretation. Saint Petersburg: Spbgupm. 228 p. (in Russ).

Zborovsky G. E. (2005) Sociology of education. M.: Gardariki. 383 p. (in Russ). 